\title{
Are We All Amazon Primed? Consumers and the Politics of Platform Power
}

Comparative Political Studies 2020, Vol. 53(2) 288-318

(C) The Author(s) 2019

Article reuse guidelines: sagepub.com/journals-permissions DOI: $10.1177 / 0010414019852687$ journals.sagepub.com/home/cps

\section{Pepper D. Culpepper' ${ }^{1}$ and Kathleen Thelen ${ }^{2}$}

\begin{abstract}
This article articulates a distinctive source of political influence of some technology firms, which we call platform power. Platform power inheres in companies of economic scale that provide the terms of access through which large numbers of consumers access goods, services, and information. Firms with platform power benefit from a deference from policymakers, but this deference is not primarily a function of direct influence through lobbying or campaign contributions, nor does it come from the threat of disinvestment. Companies with platform power instead benefit from the tacit allegiance of consumers, who can prove a formidable source of opposition to regulations that threaten these platforms. Focusing on the critical role played by consumers in explaining the powers platform firms wield in the rich democracies lends insight as well into their distinctive vulnerabilities, which flow from events that split the consumer-platform alliance or that cue citizen, as opposed to consumer, political identities.
\end{abstract}

\section{Keywords}

business and politics, political economy, platform companies, consumers, technology and politics

\footnotetext{
'University of Oxford, UK

${ }^{2}$ Massachusetts Institute of Technology, Cambridge, USA

Corresponding Author:

Pepper D. Culpepper, Blavatnik School of Government, University of Oxford, Radcliffe

Observatory Quarter, Oxford OX2 6GG, UK.

Email: pepper.culpepper@bsg.ox.ac.uk
} 


\section{Introduction}

Modern capitalism has concentrated a breathtaking degree of economic power in the hands of just a few corporations, most of which did not exist 25 years ago. Yet, corporate power is clearly a different animal than it used to be (Davis, 2015), and political science has been slow to catch on to this transformation. Today, a handful of big technology companies-Facebook, Amazon, Apple, Google, and Microsoft-exercise enormous influence in the advanced economies (Moore \& Tambini, 2018), at the same moment that the organized business elite in many countries, including the United States, has ceased to project a united political voice (Heemskerk, 2007; Mizruchi, 2013). An effective conception of the political power of business needs to be capable of understanding the variation in power held by individual firms, and not just the power of organized business as a collective body (Culpepper, 2015). This is not merely a difference in the interests of large and small companies, which has a long history in political economy. It is a recognition that a few individual players have an economic — and potentially a political —impact that past work on business power does not immediately illuminate, because in the ontology of much of political science, business is an interest group (Vogel, 1987). Yet in fact, firms in the singular form are now influential players in the economy and in politics (Collier, Dubal, \& Carter, 2018).

In this article, we investigate the political power of a number of technology companies that play the role of central intermediaries in the economies of the advanced industrial democracies - platform firms. In contrast to traditional business models based on selling goods or services, platform companies represent a new means to create and capture value through their capacity to harvest and harness immense amounts of data in ways that allow them to operate as critical market makers (Srnicek, 2016; Zysman \& Kenney, 2017). Thus, service platforms such as Uber or Airbnb connect seekers with providers of services, goods platforms like Amazon connect buyers with sellers, and information platforms like Facebook and Google connect people to each other, to advertisers, and to information. Sabeel Rahman (2018) has succinctly summarized the central role these firms play in the economic infrastructure of 21st century capitalism: "Whether it is Google's dominance of search and online information, Facebook's centrality for access to media, or Amazon's growing control over ... distribution networks for physical goods," these firms exercise broad control over the terms of access to crucial services on which a wide range of other actors depend (p. 149).

Not all, and indeed very few, firms achieve this level of influence, but those that do clearly play an outsized role in modern life. The question is, do they play an outsized role in political life - and if so, how? We argue that 
platform firms that achieve a certain economic scale - which need not reach monopoly proportions - benefit from the direct relationship they enjoy to a large number of consumers who rely on the platform as it becomes integrated into the fabric of their daily lives. Unlike previous generations of large companies on which the broader economy came to depend, such as railways or utility companies, today's largest platforms enjoy a tight, even intimate, connection to their users. Not all platform companies reach either the economic scale or the infrastructural capacity to build consumer attachment and consumer dependence. But for those that do achieve such scale and influence, the direct connection to the consumer confers a distinctive form of power. We therefore call this quantity platform power.

The classic tools of regulatory capture and the threat of disinvestmentsometimes known as the instrumental and structural power of business, respectively—do not capture the type of political influence today's dominant platform firms wield in modern capitalism. Just as not all businesses enjoy business power, not all platform companies benefit from platform power. For those that achieve dominance in a particular market, however, the political influence these companies wield is not merely a function of their size and scale. It is at this point that the study of the political power of platform firms makes a novel contribution to the literature on business influence. Market power is a necessary but not sufficient condition for platform power. The mechanism that translates market power into political clout, we argue, flows from the appreciation, verging on dependence, that consumers have for the convenience these companies provide. Because they are connected to these platforms by their smartphones, they are always only a click away from a cheap ride or a free piece of information or a swift delivery of a consumer good. Dominant platform firms cultivate and benefit from a privileged alliance with consumers, who buttress platform power by providing a formidable source of opposition to regulation that threatens the convenience provided by these platforms.

Large platform companies do not always get their way, any more than other companies that benefit from structural power always get their way in politics. Understanding their power is critical to understanding the strategies they pursue and the political challenges they face. Focusing on the role played by consumers in explaining the powers these firms wield also provides insights into their distinctive vulnerabilities. Such vulnerabilities flow from events that split the consumer-platform alliance or that cue citizen, as opposed to consumer, political identities. Thus, political issues that highlight the ways in which the interests of consumers and those of the company diverge can disrupt the alliance. Furthermore, so long as platform users think of themselves as consumers rather than citizens, these companies have a 
strong ally in public opinion, which values the convenience and innovation capacity of the platforms more than it trusts the heavy regulatory hand of government. However, the deep involvement of the platforms in the modern economy means that their algorithms can change the outcomes of elections and their privacy policies can enable them to know far more about us than governments do. When such considerations become politically salient, as Facebook has discovered recently, they prime citizen identities, leaving the public much more amenable to imposing regulation on platforms.

Our enterprise in this article is primarily conceptual-developing a way of understanding an emergent source of business power that challenges current ways of thinking. In the next section, we explore the particular features of platform firms that make them unusual, and we identify consumers and their alliance with the large platforms as the element missing in the conventional toolbox of political economists trying to understand business power. The following two sections outline how the priming of the consumer identity can most productively be understood by analogy to the idea of the permissive consensus (Hooghe \& Marks, 2009), which helps generate hypotheses about the course of political conflicts involving platform firms. Empirically, we apply this conceptual apparatus to a range of recent, high-profile cases in which platform companies were political protagonists. Putting the consumerplatform alliance in the analytical foreground helps to explain variations in the political strategies and observed political effectiveness of platform companies around the world. The final section concludes the article.

\section{Platform Companies and Business Power}

Social scientists have recently turned their attention back to classic questions of business influence in democratic politics, prompted by a combination of skyrocketing inequality and the increasing attention to the one-percent and moneyed interests in politics. Marxist scholars built some of the scaffolding for these modern debates by distinguishing between the instrumental and the structural power of business (e.g., Block, 1980; Miliband, 1969; Poulantzas, 1973). Within political science, early formulations of business power stressed direct forms of influence through iron triangles and the "power elite" (e.g., Mills, 1956). Subsequent work by scholars such as Lindblom (1977) and Gaventa (1980) explored subtler but still potent forms of business power in politics and political economy.

Recent scholarship has brought new insights into how business power in both its instrumental and structural variants is manifested and exercised in contemporary capitalism. With respect to instrumental power, we have come a great distance in refining early characterizations suggesting influence 
through outright bribery, corruption, and backroom deals. We now understand more about the wide range of resources, made possible and amplified by financial resources but reaching far beyond these, that allow economic interests to influence political outcomes. For example, Hacker and Pierson's (2017) analysis of the American Business Roundtable and Chamber of Commerce explored the organizational resources that business interests use to influence policy directly. Alexander Hertel-Fernandez's (2014) study of the American Legislative Exchange Council (ALEC) illuminated the informational resources that business interests offer to influence state legislators. The work of Hertel-Fernandez, Mildenberger, and Stokes (2019) showed how corporate interests exercise especial influence on the way congressional staffers estimate public opinion in their own districts. Culpepper's (2011) research on quiet politics demonstrated the importance of the informational advantages of business in lobbying legislatures and influencing media coverage. These and other recent works have given us new insights into the sources and nature of the instrumental power exercised by business in politics (Pagliari \& Young, 2015; Woll, 2008; Young, 2012).

Recent work on the structural power of business has similarly advanced in comparison with early formulations, providing a nuanced response to the criticism of pluralists like David Vogel (1987), who found the concept of structural power wanting for lack of evidence that business always and everywhere got what it wanted. Classic structural power arguments emphasized how business power operates in the minds of politicians in an anticipatory way. Specifically, politicians forebear in the face of the threat of business exit or disinvestment, worried about what Lindblom called the "punishing recoil mechanism"- as firms leave for more favorable business locations or invest less money, thus depressing growth and employment (Lindblom, 1982; Przeworski \& Wallerstein, 1988). In the meantime, however, the literature has moved beyond the idea of power as a fixed attribute of the business class in advanced capitalism and embraced a more relational view-a situation of "mutual dependency" between governments and business, sometimes but not always asymmetrically skewed toward business (Culpepper, 2015, p. 398). Armed with a more nuanced understanding of the nature of structural power, recent literature has made clear that the structural power of business is something that varies - over time (Hacker \& Pierson, 2002), cross-nationally (Culpepper \& Reinke, 2014; Fairfield, 2015; Grossman \& Woll, 2014; Woll, 2014), and even across different firms (Culpepper, 2015; Young, 2015). ${ }^{1}$

Despite these clear advances in understanding, traditional notions of instrumental and structural power seem challenged by the prominent role of Facebook and Amazon in the modern political economy. Clearly, such firms 
possess tremendous financial resources and have active lobbies in Washington, Brussels, and other political capitals around the world. In the United States in 2017 , companies in the Internet sector spent $\$ 50$ million on lobbying, a threefold increase since 2009 ("Silicon Valley," 2018); Amazon alone increased its spending on American lobbying to roughly $\$ 13$ million in 2017, as opposed to equivalent spending of $\$ 2.5$ million 5 years earlier (Lynch, 2017). Tech companies and their employees are large sources of campaign finance in the United States, giving three-quarters of their donations to Democrats. They have been similarly active in the European Union (EU), deploying instrumental power when regulatory issues affecting them come before the European Commission (Corporate Europe Observatory [CEO], 2018), the European Council (Cadwalladr \& Campbell, 2019), and the European Parliament (Rossi, 2016).

However, it is not at all clear that the tools and strategies of instrumental power represent the principal form of influence these companies wield. Their political strength does not flow uniquely from the amount they spend on lobbying, but in the way that the political terrain they enter is already tilted in their favor. Who wants to be the politician who shuts down my access to cheap consumer goods delivered the next day through Amazon Prime or the information gateway that connects me to the world through Facebook?

Intuitively, the power of these companies shares some similarities to older conceptions of structural power. In this case too, the form of influence companies exercise flows from the normal operation of the firm, not from something done as a sideline to their business to influence politics. In common with Lindblom's (1982) punishing recoil mechanism, platform power is largely automatic - it happens in the minds of politicians. The difference, though, is that in the case of platform power, the potential loss is not disinvestment or job loss. Amazon is a large employer, and its hunt for a new headquarters kicked off jurisdictional competition across American cities. But Google and Facebook employ relatively few people, and no one thinks that these firms are going to stop investing in the promotion of their platforms if regulation goes against them. The power these companies wield operates not through politician's fear of the pain that these firms can visit upon the economy so much as the anticipated political fallout to which overeager regulators would expose themselves by messing with the infrastructure of people's lives.

Legal scholars have been quicker than political scientists to consider the challenges that platform companies pose to regulation, focusing especially on issues of market or monopoly power (e.g., Cohen, 2016; Lynskey, 2017). The outsized power wielded by some platform companies in contemporary 
capitalism has inspired analogies to the great monopolies of yesteryear, companies such as Standard Oil and U.S. Steel (Posner \& Weyl, 2018; Rahman, 2018). What these analogies capture well is that, like the railroads of the 19th century, companies such as Google and Amazon are not just service providers in their own right. They also provide the infrastructure to which an entire economic ecosystem - consisting of myriad other businesses-is now attached (Rahman, 2018). Third-party sellers are in the meantime almost entirely reliant on Amazon (or Google shopping) to reach consumers; content creators need YouTube to monetize their videos. In this sense, traditional measures of a firm's "size" often understate platform dominance. Amazon, for example, commands a large share of the online retail market, but more importantly, it occupies a structural position that enables it to control market flows in both directions (for an extended analysis, see Rahman \& Thelen, 2019).

We do not contest the importance of the monopoly power enjoyed by some of these firms, and we note that the dominant market position many of them currently occupy is a direct function of the way in which creative entrepreneurs got out ahead of regulators to create and cultivate new markets and grow to scale before policymakers had regulated these spaces (Thelen, 2018). Just as increasing returns solidify market concentration for classical monopolies, platforms that achieve scale can exploit their competitive advantage to fend off rivals and defend their dominance. Indeed, given the centrality of network effects to the success of these companies, scale is critical to their ability "to cultivate and capture value" (Langley \& Leyshon, 2017, p. 22). As Kurz notes, the data they collect on users are a core strategic asset, so that "once an innovative firm establishes platform dominance ... cost and economies-of-scale advantages are almost impossible for competitors to overcome" (Kurz, 2017).

What is different and politically consequential, however, is that unlike the monopolies of the past, today's tech firms enjoy a direct, indeed virtually unmediated, link to their users, most of whom connect to these firms through devices they carry in their pockets every day. Companies with platform power have achieved economic scale on the back of a hand-in-glove relationship with these users. The most successful such firms have proved to be extraordinarily adept in leveraging their loyal (in many cases, effectively captive) consumer base into an active public narrative and political advocacy strategy to secure legislative and legal support for their business model. Legal approaches that stress monopoly control alone, just as instrumental and structural power approaches, assume that economic incentives are foremost in the minds of policymakers who are considering adopting regulations that constrain business. As such, all these previous formulations miss a 
critical new source of business power that stems from the connection that today's platforms have forged, and actively cultivate, with consumers whom politicians and regulators are reluctant to antagonize.

\section{Consumers and Platform Power}

With few exceptions (Naoi \& Kume, 2015; Rahman \& Thelen, 2019; Rogowski \& Kayser, 2002; Trumbull, 2006), consumers are undertheorized in the literature on the political economy of the rich democracies. This may have been understandable in the era of manufacturing dominance, but it is increasingly untenable in modern service-based economies in which consumers are clearly pivotal. Understanding the role of consumers in shoring up today's platform firms helps to make clear what distinguishes platform power from other forms of business power.

Consumers are by definition important to any capitalist enterprise, but the relationship to today's dominant platforms goes beyond familiar models of consumer loyalty or cost-based choice. Target and Walmart and Nike appeal to their consumers on price or on brand, and companies like Lego and Ikea are wildly popular with consumers. But the relationship of consumers to firms like Amazon and Uber runs much deeper, as these platforms over time have come to form part of the infrastructure of their lives. For those platforms that achieve scale, consumers can become essentially locked in, and the power these firms wield takes on "second face of power" characteristics (Lukes, 2005). The political terrain comes to be tilted in favor of the platform, and politicians rationally shy away from even entertaining policies that would deprive their constituencies of the conveniences on which many of them now rely.

Business power is classically seen as exercised against the public interest, and in fact the litmus test for structural power has often required the analyst first to demonstrate that what business wants "pushes against substantial opposition in government or in public opinion" (Culpepper, 2015, p. 397). By such a standard, however, today's platform firms mostly fail the test. To the extent that Google delivers superior (faster and better) search results, and to the extent that Amazon makes shopping easier and less expensive, the power of these companies (in the short-run anyway) is clearly exercised not against the public but in a close and symbiotic alliance with a public that has come to depend on them. This allows platform firms to portray themselves as promoting the interest of consumers in efficiency, innovation, and choice. This is power that is exercised not against but often decidedly with a public that enjoys the fruits of innovation. In this sense, platform firms have succeeded in getting what they want because the public wants it too. 
These features also distinguish today's platforms sharply from traditional monopolies. Platform firms share with contemporary (publicly regulated) natural monopolies, such as electricity companies, scale advantages that allow them to provide goods at a cheaper cost. We are all dependent on access to the electric grid, and it is certainly convenient to have the lights stay on and keep my iPhone charged. The risk is that with such market dominance, natural monopolies can raise prices on consumers, who would then not have alternatives, and would be forced to pay monopoly rents. Being plugged into the electricity grid, I qua consumer am dependent on a power supplier, and I want the state to check that power. That sort of dependence creates a potential for a politician-consumer alliance in favor of regulatory politics.

Like natural monopolies, the efficiency gains of today's tech platforms are above all a matter of their massive scale and scope. Very differently, however, from most public monopolies, these platforms (at least at this stage in their development) feel to the consumer like liberation from market distortions that keep them from getting the lowest price for a ride (Uber) or prevent them from finding publicly available information (Google). ${ }^{2}$ Being plugged into the Internet market via Amazon, I qua consumer am liberated from the need to go to brick and mortar stores. This creates hostility to state regulation that threatens to take away the advantages brought to me by my preferred platforms. Who loves their electricity company? No one. That is not the case with companies that exercise platform power, and this situation creates a bias in favor of deregulatory politics, where consumers and the dominant companies are on the same side-against state intervention.

In short, platform firms share with popular companies such as Lego a strong and loyal customer base and with classic monopolies such as U.S. Steel size and scale advantages that give them a massive edge over competitors. What is distinctive and distinctively powerful, however, is the combination of these features. To put it somewhat crudely: consumers depended on U.S. Steel, which exercised infrastructural power, but they did not love the company or actively appreciate the advantages (if any) that it afforded them. By contrast, consumers love Lego but they are not dependent on the company in the same way that they are dependent on, say, Amazon, which actually allows them to order their Legos without having to change out of their pajamas. The platform in platform power thereby does important work for these companies.

Our treatment of consumer preferences for regulation is admittedly somewhat stylized: if a regulation does good for consumers without having any effect on their ability to enjoy the convenience delivered by platform innovation, there is in theory no reason consumers should oppose regulation. ${ }^{3}$ As 
Table I. YouGov's Global Health Brand Rankings 2018.

\begin{tabular}{ll}
\hline I Google & 6 Amazon \\
2 YouTube & 7 lkea \\
3 Samsung & 8 Colgate \\
4 WhatsApp & 9 Uniqlo \\
5 Facebook & 10 Lego \\
\hline
\end{tabular}

Source. YouGov Brandlndex (https://yougov.co.uk/topics/resources/articles -reports/2018/07/26/google-keeps-top-spot-yougovs-global-brand-health-). The brand index score includes perceptions of brand quality, value, impression, satisfaction, reputation, and whether consumers would recommend to others.

long they do not effectively shut down a platform, regulations that, for example, attempt to enhance competition or to give consumers control of how their data are used could be welcomed by consumers. Research does suggest some limitations to these conjectures, however. First, there is large body of research on the privacy paradox, some of which establishes that consumers may claim in surveys to like privacy but will in their actual behavior sacrifice it in exchange for modestly lower prices or greater convenience (see Kokolakis, 2017 for a review). Second, different individuals hold distinct preferences with respect to the costs and benefits of various forms of regulation, as for example young UberPool users with limited resources may be warier of regulations that could raise prices than their UberBlack-client elders. Or, as argued by Strahilevitz (2013), consumers who are less concerned about privacy issues may be aligned, if only by default, with companies who oppose strict data protection regulation. ${ }^{4}$ And, finally, as we will discuss below, consumers in at least some national markets trust businesses to self-regulate more than they trust governments to regulate. Each of these reasons suggests that our simplifying assumption of a significant level of general consumer aversion to regulation of innovative platform companies, absent the sort of citizen priming we introduce below, is consistent with observed patterns of consumer behavior in this rapidly evolving policy domain.

Consumers' high regard for today's dominant platforms - and their appreciation of the astonishing benefits they deliver through our cell phones-is evident in global indices of company popularity. In the 2018 global brand health rankings created by the polling firm YouGov, platform companies took five of the top six places (Table 1).

Complementary polling results suggest that consumers the world over not only like these companies but also trust them. The Edelman Trust Barometer 
Table 2. Trust in Industry Sectors, 5-Year Trend.

\begin{tabular}{lccccc}
\hline & 2014 & 2015 & 2016 & 2017 & 2018 \\
\hline Technology & 75 & 73 & 74 & 75 & 74 \\
Automotive & 69 & 66 & 60 & 65 & 62 \\
Entertainment & 64 & 63 & 64 & 64 & 62 \\
Financial services & 48 & 48 & 51 & 54 & 54 \\
\hline
\end{tabular}

Source. Edelman Trust Barometer (2018, p. 46) (https://www.edelman.com/sites/g/files /aatuss | 91/files/2018-I0/2018_Edelman_Trust_Barometer_Global_Report_FEB.pdf).

compiles globally comparable data on trends in the trustworthiness of various industries. The technology sector, which is dominated by platform firms, has led that indicator for the past 5 years, and indeed its performance has hardly budged. In response to the prompt, "Please indicate how much you trust businesses in each of the following industries to do what is right," the technology sector stood at $74 \%$ in 2018 . No other industry had a score higher than $62 \%$ that year (Table 2).

Such trust underpins the consumer-platform alliance against government regulation, particularly in countries such as the United States that anyway have a limited appetite for government intervention in markets. In a survey fielded in early 2018, the Pew Research Center probed American preferences on how to police the dissemination of fake news on social media. Against the backdrop of a national discussion of the role of fake news in the 2016 American presidential election, the survey asked a nationally representative sample of American adults who - tech firms or government - should regulate the dissemination of false information online? The results pointed to a striking preference on the part of citizens for self-regulation through the tech companies rather than government regulation of fake news.

As shown in Table 3, only 39\% of Americans thought the U.S. government should restrict the flow of false information online, while in response to otherwise identical question wording, $56 \%$ of Americans thought technology companies should perform these functions. And this finding came in the wake of a scandal in which technology companies were the critical channels through which false information flowed into a presidential campaign. Although we lack the data to know whether this specific impulse exists in public opinion outside the United States, the general popularity and trust of consumers for technology companies that we have documented in this section is an international phenomenon, one that serves the political interests of large platform firms in a variety of countries around the world. 
Table 3. Government Regulation or Company Regulation of Fake News? $(N=4,734)$.

\begin{tabular}{lccc}
\hline & \% Agree & \% Agree \\
\hline The U.S. government ... & 39 & $\begin{array}{l}\text { Freedom of information } \\
\text { should be protected, } \\
\text { even if it means false } \\
\text { Tech companies ... }\end{array}$ & 58 \\
$\begin{array}{l}\text { information can be } \\
\text { restrict false info online, even } \\
\text { if it limits freedom of info. }\end{array}$ & 56 & published. & 42 \\
\hline
\end{tabular}

Source. Mitchell, Grieco, and Sumida (2018, p. 3).

\section{Permissive Consensus and Its Empirical Implications}

If platform firms have consumers as their natural allies, how do they ever lose regulatory battles? Our theoretical position draws on the priming literature in social science, which posits that individuals have multiple identities, the salience of which can influence their political preferences on a given political issue. Most notably, we are all citizens and consumers. Priming citizen identity can lead to more sociotropic preferences, while priming consumer identity can lead to a narrower focus on individual self-interest.

Empirical support for this proposition can be found in the area of international trade preferences, where Naoi and Kume (2015) show that the priming of consumer identities in Japan raised support for free trade by up to $9 \%$ compared with a control group. This insight builds on the work of Baker $(2003,2005)$, who argued that consumer preferences explain some part of the cross-country variation in policies for trade liberalization. It can also be found in the field of psychology, where experimental research has shown that cuing consumer identity, as opposed to "citizen" or "individual" identities, increases materialistic aspirations and decreases levels of social trust and feelings of responsibility in common pool resource dilemmas (Bauer, Wilkie, Kim, \& Bodenhausen, 2012).

Capital and labor platforms are directly oriented to the consumption of goods and services. Information platforms such as Google work on the premise of targeted advertising, exposure to which can readily cue consumer identity. So long as their alliance with consumers lasts, the tacit support of consumers is a powerful source of advantage for platform companies. But when publics turn against them, these firms are vulnerable. To sharpen our expectations about why platform power varies, we need a conceptual apparatus that allows us to understand the sources and limits of consumer support for 
platform firms. When does the consumer identity dominate preference formation, and when is it subordinated to citizen or other aspects of identity?

The orientation of today's consumers with respect to companies enjoying platform power can perhaps best be made by analogy to what Hooghe and Marks (2009) called the permissive consensus in public opinion. The permissive consensus held that public opinion across member states of the EU was broadly positive toward the European project, and that this positive orientation gave political leaders some freedom to craft new institutional deals about the evolution of the EU. This expansive attitude lasted only so long as the EU was not perceived by citizens to intrude on the core issues of political difference that structured national political competition (Scharpf, 1999). The permissive consensus was seen to have died in the wake of the Maastricht Treaty, which set up the process for adopting the single currency that became the euro. This policy development brought the institutional evolution of the EU into the realm of redistributive political questions: the ability to conduct one's own monetary policy and the limits of permissible public spending and borrowing. These issues were at the core of national differences among member states, and the political salience of the European dimension of politics thus became much more intense. The public began to think of the EU not as a simple broadening of the market that brought them cheaper goods, but as a constraint on the ability of national governments to deliver the public policies demanded by their populations.

The permissive consensus usefully reminds us that the support of consumers may be drained away when the politics of an issue intersects with the core concerns of people as citizens rather than as consumers. So long as the consensus holds, consumers enjoy the free lunch delivered by radical technological innovation. Their political orientation in such situations is likely to be a permissive one, which favors the assumption of company freedom to promote innovation. At the same time, however, consumers are not (always) fools. They are at least aware that big companies do not always have their interests at heart.

We expect a breakdown of the new permissive consensus in two sorts of situations. The first is one in which a political issue becomes framed in ways that directly pit the interests of the consumer against the interests of the platform companies. The second situation in which the permissive consensus will collapse is one in which political events prime consumers to think of themselves as citizens first, with the sociotropic concerns of citizens, as opposed to consumers first. The latter situation may not involve interest conflict between consumers and platforms so much as interest conflict between citizens and platforms - and all consumers also have a citizen identity, no matter how much time they spend online. 
Conceiving of consumer support as a new permissive consensus allows us to generate empirical expectations about the political strategies of platform firms and the conditions under which they succeed and fail. Platforms such as Google and Facebook, which exchange access to information for the data of users, have created and now dominate new markets and services. Once these firms reach scale, it is not so much consumer loyalty that inspires the coalition between users and platform as consumer dependence. The dependence is in some sense mutual, in that these information platforms depend on the consumer's willingness to trade their data in return for free use of the platforms and the convenience the platform provides. The key to making this deal sustainable is to have brands that consumers have no reason to mistrust-in other words, when Google says "don't be evil" is its motto, that consumers believe it. When they do lose consumer trust - even if they maintain nearmonopoly power in a market - we expect a rapid loss of political capital. And when the only thing keeping regulators from imposing new rules is the fear of consumer backlash that translates into this empirical expectation: platform companies that suffer substantial losses of consumer confidence are likely to suffer regulatory losses, regardless of whether their share price or market share is affected.

Where platforms can plausibly present themselves as representing consumer interests - for example, as champions of choice and innovation fighting against over-regulation-elected politicians have reason to tread carefully in making laws that affect platform companies. Other things being equal, we therefore expect platform companies to regard appeals to the broader public to be much more attractive than they typically are for nonplatform companies. Consumers as a group are often organized into politics with associational structures or legal protections that see them as having conflicting interests to business (Trumbull, 2006). Consumer protection law is after all based on the principle of protecting consumers from someone, and that someone is business. But with carefully cultivated reputations for competence and deep ties to the consumers who depend on their services, platform companies often think they are likely to benefit from including the consumer viewpoint.

This claim has implications for the ways in which we expect platform companies to engage in politics. According to this logic, platform companies are more likely than non-platform companies to engage in broad-based political campaigns, pitting their popularity against those of their opponents. It is worth underlining that this is a radical departure from the standard operating procedure of big business, as well as from the expectations of the literature on regulatory capture. Business typically prefers to deal with regulators or courts rather than with legislatures as a venue for action (Dür, Bernhagen, \& 
Marshall, 2015). Regulators put a premium on expert knowledge of the subject and carefully crafted argument, while legislatures are considered more volatile and thus less reliably pro-business. Representatives of business have traditionally engaged in forum-shopping, to find the arena in which the tools of quiet politics are most effective. The preferred arena of conflict for business is typically a regulatory conference room rather than a public parliamentary hearing (Culpepper, 2011).

Platform companies are as likely to forum-shop as any other business, but they sometimes have good reason to prefer incorporating the public - and the legislative actors likely to be moved by public opinion - even as they try to influence public views on quickly changing questions of policy. Where independent bureaucratic agencies or courts regulate platforms, those bodies are by design more politically insulated from popular influence. We expect this insulation to diminish the influence of platform power in front of regulators such as the European Competition Network. Where issues are in the courts or with regulators, we may nevertheless expect to see platform companies draw in the public to try leverage the consumer alliance as a weapon in their favor.

\section{Platform Power in Practice}

The recency of the rise of platform power as a phenomenon limits our ability to test these propositions systematically. There are a number of politically important and geographically diverse instances of political contestation involving platform firms, and we draw on these in this section to illustrate the productive application of platform power to this emerging field of politics. In the first part of this section, we examine temporal and spatial variation in the success of platform power, depending on the way in which public debates highlighted the convergence or divergence of interests between platforms and their users. In the second part, we show how platforms try to capitalize on their popularity with consumers to achieve political goals. And in the final part of this section, we examine the strategies of one influential platform company to address a misalignment between its consumer base and the seat of political authority, which the company recognized and sought to change to its advantage.

\section{Alignment of Consumer and Platform Interests as a Variable}

Platform companies are as vulnerable as any other company to events that show them in a bad light with the public. But the nature of their vulnerability has distinctive characteristics, tied to the ways in which the salience of some issues undermines the alignment of interests between consumers and 
platforms or prime citizen identities as opposed to consumer identities. Issues that put the consumer and the platform on the same side will have trouble gaining traction in the public eye. For example, Amazon's Prime delivery service is predicated on harsh labor practices that allow the company to deliver goods more quickly and cheaply than ever before. However, taking a hard look at what makes it possible for the company to fulfill our shopping needs so swiftly and inexpensively would require consumers to share blame in the exploitation these practices entail. Consumers are unlikely to mobilize around this issue since they themselves are complicit in it. To update the famous observation of Upton Sinclair, it is difficult to get a person to understand something when the cheapness of their goods and services depends on their not understanding it.

Other issues, however, directly undermine the perception of the platform company and its consumers as notional allies. For example, in the case of information platforms that trade data for services, scandals that focus attention on what is happening with individual data are particularly damaging because they activate privacy concerns and alert consumers to the reality that the information they are getting in fact comes at a cost. One early and notable instance of this political dynamic took place in the EU in the wake of the 2013 revelation of Edward Snowden about data collection practices of the U.S. government. ${ }^{5}$ At the time, the European Parliament was already well advanced in developing draft legislation to govern privacy, the Global Data Protection Regulation (GDPR). Before the bombshell dropped by Snowden's release of information on how data were being collected, the GDPR had attracted sustained lobbying from private companies but very little public attention. However, as Figure 1 illustrates, the Snowden affair immediately raised the public profile of the GDPR discussion, and it did so in a way that put platforms on the same side as government intelligence agencies, and on the opposite side of European private citizens who used the Internet (Rossi, 2016).

The Snowden episode revealed that platform companies were the key vector through which the American and British intelligence agencies had been gathering data, directly from the servers of "Microsoft, Yahoo, Google, Facebook, PalTalk, AOL, Skype, YouTube, [and] Apple" (Gellman \& Poitras, 2013). As Rossi (2016) in particular has shown, these events caused a stark reversal in how consumers perceived the major platform companies, which were no longer viewed as benign resources for sharing information but as active collaborators in the project of government surveillance (see also Ash, 2013; Packer, 2013). That is, the Snowden revelations drove a wedge into the alliance between platforms and consumers by revealing to consumers that there was a hidden cost of their reliance on information platforms. The 


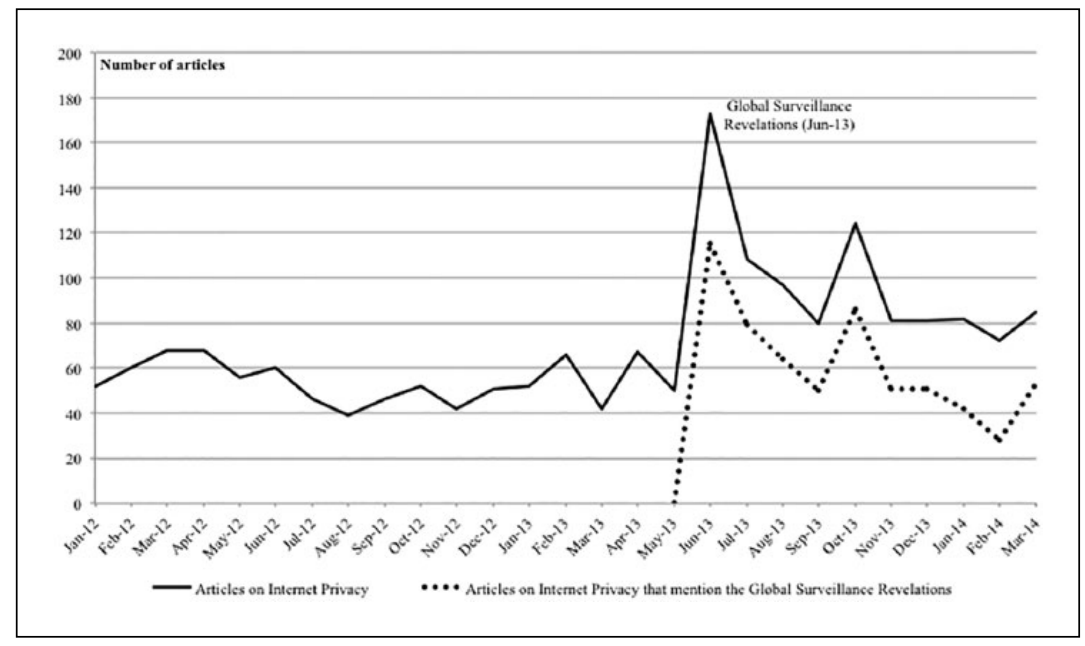

Figure I. Salience of Internet privacy and Snowden revelations.

Source. Rossi (2016, p. 3I). Data are from Lexis Nexis for the largest two newspapers in each of France, Germany, Italy, Spain, and the United Kingdom.

ensuing public outrage contributed to a significant strengthening of the GDPR (Rossi, 2016).

The more recent Facebook scandal brought the same issue home to American consumers. Facebook was scraping private data all along, completely under the radar until Cambridge Analytica brought high salience to privacy issues, and in a way that made consumers worldwide ask what Facebook was doing with their data. Suddenly the company became politically vulnerable, as evidenced by the copious portions of humble pie consumed by CEO Mark Zuckerberg in the wake of the news about Cambridge Analytica. One poll of American adults, taken just after outbreak of the scandal in early 2018, showed that $56 \%$ of people named Facebook as the tech company they trusted least; the next least trusted was Google, with 5\%. ${ }^{6} \mathrm{~A}$ poll commissioned by Fortune in October 2018 showed that Facebook remained the company least trusted by consumers with their personal data, with only $22 \%$ expressing a lot or a fair amount of trust in the company (Amazon led the poll, with $49 \%$ expressing a lot or a fair amount of trust). ${ }^{7}$ Although it is too early to assess the full political fallout of the Facebook scandal, one early result was a sweeping new online privacy law in the company's home state of California, a law that sailed through the state legislature ("from draft to law in one week") with strong bipartisan support. ${ }^{8}$ In this case as well, we would argue, Facebook's vulnerability came from the fact that the 
data scandal drove a wedge between the company and its users, at least temporarily.

Indeed, the recent travails of Facebook illustrate that the privacy issue specifically may be the Achilles heel of information platforms. This is an area in which these firms have reason to fear the specter of a user-regulator alliance against the platforms. The permissive consumer consensus that has allowed their conquest of new markets can give way to a more malign consumer view, one that involves thinking twice before mindlessly accepting the terms and conditions of use in a pop-up notification. In this view, an information platform's domination of and access to information can come to be seen by consumers as a scary invasion of privacy, which needs to be regulated. Its ability to distort information, in response to advertising algorithms or Russian hackers, can lead to a problematic perversion of the public sphere. The salience of privacy is thus the most pressing political concern of these companies, because a consumer focus on privacy undermines the notion that consumers are getting a good deal by trading their data for access to information.

Looking beyond information platforms and privacy issues, we also observe variation in the relative salience of different issues, depending on the details of political contestation and media coverage in different polities. Some issues are more likely to prime citizen rather than consumer identities (Naoi \& Kume, 2015). When that happens, we expect platforms to face greater political headwinds. The contrast between Uber's reception in the United States and Denmark can serve as an example. Almost everywhere, Uber's arrival was met by ferocious opposition from established taxi companies, but from that point on, the politics often diverged in different countries (for a full analysis see Thelen, 2018).

In the United States, Uber was able to frame the conflict on terms favorable to itself, portraying its own role as promoting innovation and consumer choice against inefficient, rent-seeking local taxi monopolies. Uber also pioneered and perfected the strategy of using its app to mobilize consumers and apply pressure on politicians through social media campaigns. Indeed, Uber in 2017 included in its terms and conditions the following language: "Uber may also use the information [we collect] to inform you about elections, ballots, referenda and other political and policy processes that relate to our services." When faced with the prospect of unwelcome regulation, the company often responded by adding a tab to its app through which users could register their disapproval to the city government with the push of a buttonso much easier than writing a letter or marching on city hall! (Thelen, 2018, p. 7). As Collier et al. (2018) emphasize, Uber was thereby able to channel the way in which the preferences of "the public" were presented, "solving" consumers' collective action problems while also controlling the message 
they sent to policymakers. Such strategies are often rhetorically and politically powerful, allowing these firms to portray themselves as defending the consumer against "stifling" regulation in the interests of efficiency, innovation, and consumer choice.

In Denmark, by contrast, the central flashpoint around which the conflict over Uber centered was taxation. ${ }^{10}$ Taxi companies drew attention to the possibility that Uber's competitive advantage was underwritten by widespread tax evasion on the part of drivers, and in so doing, they enlisted tax authorities, unions, and most political parties as allies in the fight. Danish unions, concerned about the financial underpinnings of a welfare regime that relies heavily on tax-financed universalistic benefits, took up the cause with gusto. The country's largest union, 3F, hired a public relations firm that employed a well-known Danish comic actor to produce a series of videos featuring "Poul Uberman," who touted the benefits of the new service, only to have work colleagues or his mother-in-law in a nursing home highlight how Uber was undermining core services of the welfare state. The Danish-language films went viral, achieving over 2.4 million views in a country of 5.7 million people. ${ }^{11}$ Politically, the union's campaign made taxes and the welfare state the salient points in the discussion over Uber Denmark, attaching labor's concerns to a broader coalition that channeled the interests of "the public" around a discourse centered on community norms of fairness. The point is that people can be primed to respond as consumers or as citizens. The Danish unions were able to reframe the issue of Uber's entry into the marketappealing to voters as (tax-paying) citizens rather than (convenience-loving) consumers - a winning strategy, since it cast Uber as being premised on a business model that was at odds with the preservation of a national system that works only if everyone is paying their fair share.

\section{Platforms Appeal Directly to the Public_-"Who Could Possibly Be Against This?"}

Platforms have disrupted many markets, often to the delight of consumers and to the chagrin of regulators. As a result, we argue that appealing over the heads of lawmakers or regulators to the public is a strategy that platform companies are more likely to use than other non-platform companies. Many companies run PR campaigns. But for platform companies, given their appeal to consumers, openly political campaigns are likely to be part of the strategy, because they think they can win them.

Illustrative of this dynamic are Amazon's early efforts to resist taxation of Internet sales in the United States (see especially Hertel-Fernandez, 2019, pp. 130-133). The early days of the online retailing boom were governed by 
a 1992 Supreme Court ruling (Quinn v. North Dakota), which held that states and localities could only tax retailers that had a physical presence in their jurisdiction. The prevailing rules thus gave platforms such as Amazon (and Overstock.com and ebay) clear sailing across much of the vast American market. However, after the 2008-2009 financial crash, large states such as California and New York confronted intense fiscal pressures and began to look for ways to tax the ballooning Internet retail sales market.

Amazon's response was telling. In California, the company teamed up with Overstock.com to promote a referendum campaign against the resulting legislation. Amazon poured millions into an initiative that flew under the banner "More Jobs Not Taxes" (Lifsher \& Chang, 2011). In the words of the company's vice president for global public policy: "We support this referendum against the recent sales tax legislation because, with unemployment at well over 11 per cent, Californians deserve a voice and a choice about jobs, investment and the state's economic future" (quoted in Jopson \& Garrahan, 2011). The referendum was opposed by brick-and-mortar competitors including Walmart, Home Depot, Best Buy, and Target, whose lobbying group (Alliance for Main Street Fairness) complained that "the lengths Amazon will go to evade collecting sales taxes - even spending tens of millions of dollars on a ballot initiative - should concern all Californians" (quoted Jopson \& Garrahan, 2011). The referendum campaign was called off when Amazon reached a deal with legislators to delay collection of sales taxes for a year.

A similar New York law imposing sales tax on Internet retailers prompted Amazon to turn to the ALEC, a pro-business group, to try to stanch the tide of state legislation by discussing with the organization "how to mobilize grass roots opposition to new state sales taxes" (2010 ALEC Task Force Agenda, quoted in Hertel-Fernandez, 2019, p. 132). The company's efforts through ALEC were successful in "staving off further state action for several years" (Hertel-Fernandez, 2019, p. 132), until the conflict moved to the courts, where the company was less successful. The New York State Court of Appeals upheld that state's law, a ruling that was reinforced when the U.S. Supreme Court declined to consider the case (Stohr, 2013). ${ }^{12}$

The 2015 battle between Facebook and the telecommunications regulator in India similarly illustrates the platform preference for a public political fight. ${ }^{13}$ As part of a project initially titled Internet.org, Facebook proposed to offer Indian consumers a free, stripped-down version of the Facebook app. The app, whose name was changed to Free Basics, disallowed VOIP (voice over Internet protocol) calling services and reserved the right for Facebook to reject other services. As initially explained by Facebook CEO Mark Zuckerberg, the idea was for tech and telecom companies to provide "free 
access to basic Internet services in a way that enables everyone with a phone to get on the Internet and join the knowledge economy while also enabling the industry to continue growing profits and building out this infrastructure" (cited in Prasad, 2018, p. 417). The Free Basics proposal ignited opposition in India, spearheaded by a loose coalition of technology workers and other young professionals who called themselves "Save the Internet" (STI; Soni, 2016). STI released viral videos mocking Free Basics as an attack on the principle of net neutrality. Facebook retaliated with a publicity campaign that cost \$45 million and featured billboards promoting "digital equality." Zuckerberg himself published an op-ed in the Times of India in which he asked, "Who could possibly be against this?" (Hempel, 2018). Zuckerberg and the Indian Prime Minister, Narendra Modi, held a joint town hall meeting at Facebook headquarters in Menlo Park, California, in September 2015.

The ultimate decision about Free Basics was taken not in parliament, but by the Telecom Regulatory Authority of India (TRAI). TRAI held several rounds of public consultation in 2015, in which both STI and Facebook actively campaigned for individuals to leave comments supporting their respective political stances. TRAI officials repeatedly accused Facebook of not following the appropriate procedures of such a regulatory consultation, claiming the company had submitted "a templated response" to their queries, rather than actually answering the questions posed by TRAI. The regulator also challenged the company's "self-appointed spokesmanship" on behalf of its users, without their consent, observing that "your urging has the flavor of reducing this meaningful consultation exercise designed to produce informed decisions in a transparent manner into a crudely majoritarian and orchestrated opinion poll" (Soni, 2016; our emphasis). In February 2016, TRAI ruled against Free Basics, determining that differential pricing and "zerorating plans" violated net neutrality in India (Prasad, 2018).

Platforms do not always prevail in highly politicized public campaigns, as the case of Uber Denmark showed, and they cannot always control the venue in which the conflicts are ultimately decided, as the Free Basics case demonstrated. The point, rather, is that what distinguishes platform firms from most other types of business interests is that their capacity to mobilize consumers means that they do not always seek out the familiar terrain of quiet politicsand indeed on some issues, they may be actively spoiling for an open political fight.

\section{How Platforms Forum-Shop}

The capacity of companies to enlist consumers as allies, however, depends on having sufficient concentrations of them in a relevant voting jurisdiction. In 
other words, companies can only mobilize consumers politically when the consumers are themselves electors of the politicians whose jurisdiction they wish to influence. Thus it matters whether a platform service is consumed by locals (as in the case of Uber) or instead by visitors (Airbnb) to whom local politicians may not feel particularly beholden, and indeed may be cross-pressured by local citizens with competing interests. Platforms whose services are consumed locally, such as Uber or Lyft, typically benefit from an expanding user base, as more and more consumers come to rely on the service. Platforms that benefit from these sorts of dynamics understand the political potential this implies and are not shy about exploiting it by weaponizing their users when threatened with regulation.

By contrast to the rather warm reception Uber enjoyed in most American cities (see especially Tzur, 2017), Airbnb's growth in large cities has often prompted a backlash. In New York City, for example, it triggered a countermovement that brought together a wide range of local interests who do not often find common cause. Thus, Airbnb confronted a coalition of hotel unions, industry leaders, affordable housing advocates, tenants, and senior citizens (under the moniker "Share Better"; see, for example, Dubin, 2014). ${ }^{14}$ Share Better ran a $\$ 3$ million grassroots campaign that rallied around the goal of preventing the trend of taking personal homes off the market by renting units to tourists on the platform. ${ }^{15}$ Airbnb attempted to

rally its hosts to fight . . . but it turned out to be too little too late. Airbnb's customer base is scattered around the country and the world - not ideal for lobbying legislators who listen to their own constituents. ("No Vacancy," 2017)

Similar dynamics played out in other cities including San Francisco, New Orleans, Seattle, and Berlin. The result in many of the most lucrative urban markets has been to envelop the company in stronger regulations involving some combination of registration requirements for Airbnb hosts, rules on the length of allowable stays, arrangements for payment of taxes, and other measures that have placed limits on the company's growth within particular jurisdictions.

Airbnb's response to political opposition expressed by city governments in Europe shows that it understands the need to align its political strategy with its consumer base. Faced with pressure from localities like Barcelona and Paris, the company has taken its lobbying to the EU level. Europe as a whole has a lot more tourists looking for deals on rooms than Barcelona or Berlin do. Armed with a better match between its user base and jurisdictional authority, Airbnb has pressed at the level of the European Commission for rules that favor the sharing economy and limit local initiatives that curb the 
use of Airbnb and services like it. This lobbying has led to interpretive rulings from the European Commission that allow platform companies not to share their data with local jurisdictions and that require Commission approval of efforts to place quantitative limits on the amount of housing rented through the sharing economy (CEO, 2018).

As a lobbyist, the legitimacy of Airbnb representatives is reinforced by the perception that the company is on the side of the consumer, even if they are lobbying against actual consumer groups. According to Michela Vuerich of the consumer group ANEC, Airbnb's efforts acquired legitimacy with EU policymakers because of the company's perceived connection to consumers: "what I found frustrating is that Airbnb is often seen as representing the consumer view in meetings, while they obviously represent their business only ..." (CEO, 2018, p. 11). We contend that the reason Airbnb can effectively don the mantle of consumer advocate is because consumers have come to depend on the platform as a way to avoid high hotel prices.

Politicians are more likely to bend to platforms where the platform's users are their own voters, which helps to explain why mayors across a range of cities in different countries have imposed more regulations on Airbnb than Uber. Airbnb has sought to turn the tables by taking its bargaining to the EU, where it can claim to speak for consumers across Europe, as opposed to local governments that are not responsive to consumers who live elsewhere.

\section{Conclusion}

Social science generally lags behind the world that it studies, and probably more so when economic and technological changes are proceeding as briskly as in the current moment. It seems incontrovertible that some platform firms exercise outsized power in many political economies today, and notably in the United States and the EU. We expect that Tencent and Alibaba are similarly disrupting the world of those who study corporate power in China, though the representative democratic context is a likely scope condition for the sorts of dynamics of influence we have put forward here. What we do know is that the conventional concepts of instrumental and structural power do not capture well the political strengths that Facebook, Google, and Amazon exercise in the modern economy. Likewise, although their size and market power-and associated legal debates over monopoly control-are very important for the future political influence of these companies, a simple market power view misses what is most distinctive about the political advantages enjoyed by platform firms.

Many of those advantages flow from the way that consumers experience the fruits of radical platform innovation. Both instrumental and 
structural power have emerged from a conceptual worldview according to which there is a demand for public policy that captures a governing majority in parliament, which business is then able to thwart (Fairfield, 2015). By bringing in to our analysis consumers, who enjoy an intimate dependency on the platform companies, we highlight that radical innovation has brought us radically different potential monopolists than in the past. These companies are good at quiet politics, but they do not require it to get their way. Some of these companies can actively mobilize consumers, while others can count on a wellspring of trust and dependence. "What would we do without Amazon?" may not excite the revolutionary fervor of class warriors, but it is an effective statement of a distinctive source of the power that Amazon enjoys in today's politics. In much of political economy, consumers have been left outside of the central models of political conflict, or if included as consumers, included as voters who consume. We reverse that identity: the bulwark of platform companies in democratic countries are consumers who vote.

We have drawn attention to Lindblom's work on volitions and the potential impact of business power on citizen preferences. To the extent that people come to prefer what powerful platforms want, they become tacit or even active supporters of policies that may harm their objectively defined material interests. Defenders of such a view might usefully point to the fact that Google can influence where we go on the Internet by its auto-complete function; Facebook is the news portal of choice for many; and Jeff Bezos, the founder and CEO of Amazon, has bought the influential U.S. newspaper, the Washington Post. Indeed, the machine learning capacities of Google and Facebook may allow them to predict consumer preferences better than consumers themselves can, and that capacity may have important political implications for preference formation. ${ }^{16}$ The influencing of public opinion is an important source of business power, and it certainly has a role to play in the political arsenal of the platform firms, particularly given how they depend on a reservoir of public goodwill for their political influence. Yet platform companies in these respects resemble companies in other sectors more than they differ from them. And where they differ from them is in the way they benefit from consumer dependence and the terms of the new markets they have created for consumers.

Our broader intellectual objective in this article is to open up the discussion on business power in at least two ways. First, we think that the radical innovation associated with platform companies is not the last and possibly not the most significant change in business power in 21 st century capitalism. Understanding the new sources of business influence requires grasping what is new about the new economy while putting it in the context of what 
we know about existing sources of business influence. Technological change does not merely lead to an updating of old ways of doing things; sometimes it leads to profoundly new modes of influence peddling. Second, and less boldly, we build on the work of prior scholarship in making a plea for a more central role for consumers in the study of political economy (Naoi \& Kume, 2015; Rahman \& Thelen, 2019; Rogowski \& Kayser, 2002; Schor, 1999; Trumbull, 2006). The way in which consumption defines political preferences, and the way it intersects with older and more organized cleavages such as that between labor and capital, seem to us promising exploratory avenues for modernizing how we think about power in politics and the economy.

Finally, however, we want to end on a cautious note. While the relationship between key platform firms and consumers is critical to what we call platform power, we remain skeptical about the possibility that unorganized consumers can play an effective role in durably countervailing the political influence of platform companies, whether considered individually or collectively. We have discussed the role of exogenous privacy shocks in weakening the influence of platform firms at particular legislative moments: during the amendment process of the EU's GDPR legislation in 2013 and possibly in the present moment, with the repeated revelations about Facebook's lax protection of users' data. These are politically consequential events, and they have the capacity to overturn the permissive consensus that has until now been a strong source of platform power. But the aftermath of the Snowden revelations reminds us that consumers can get angry, but they also have short memories. If democracies do decide that platform power gives these companies unfair advantages in politics, then we suspect that the role of consumers will be only part of the story. Indeed, we have suggested that courts and competition authorities may pose the biggest threats to platform power, precisely because of their relative insulation from consumer pressure. We predict that if the power of these companies is to be countervailed in a durable fashion, these are the actors who will lead that change.

\section{Acknowledgments}

The authors thank Mark Blyth, Werner Eichhorst, Patrick Emmenegger, Alexander Hertel-Fernandez, Akshay Mangla, Jim Morone, Sabeel Rahman, Joshua Simons, Cornelia Woll, three anonymous reviewers, the editors of CPS, and the participants in Blavatnik School of Government's conference on the Crisis in the Theory of the Firm in June 2018 and the MPIfG workshop on the American Political Economy in January 2019 for comments, Megan Beretta for research assistance, and the Stellenbosch Institute for Advanced Study and the Department of Business and Politics at Copenhagen Business School for institutional support. 


\section{Declaration of Conflicting Interests}

The authors declared no potential conflicts of interest with respect to the research, authorship, and/or publication of this article.

\section{Funding}

The authors received no financial support for the research, authorship, and/or publication of this article.

\section{ORCID iDs}

Pepper D. Culpepper iD https://orcid.org/0000-0001-6227-0813

Kathleen Thelen (iD https://orcid.org/0000-0003-4102-8504

\section{Notes}

1. Of course, as especially Emmenegger (2015) and Culpepper (2015) point out, while instrumental and structural power may be distinct analytically, they are closely intertwined empirically.

2. We do not exclude the idea that some of these companies may effectively exercise a stranglehold on certain markets, such as the dominant position of Amazon Marketplace in online commerce. But the form of influence about which we are writing does not flow primarily from the economic sources of monopoly power such as railroads, in which natural monopolies are the only possible providers of a service. It flows from a technological capability from which consumers do not want to be liberated and whose capacity for radical innovation is attractive to politicians, regardless of whether they are monopolies or not.

3. We thank an anonymous reviewer for emphasizing this point.

4. Such variation in privacy preferences may be a function in part of personal disposition (what Strahilevitz calls data fundamentalists vs. data unconcerned, or extroverts vs. introverts). Beyond this, however, sophisticated users may also be less concerned because they can take advantage of tools to limit access to some of their data, while continuing to enjoy options (say, for example, Google timeline) that rely on personal data they are willing to give up.

5. The following paragraphs rely on evidence from the $\mathrm{PhD}$ dissertation of Agustin Rossi (2016).

6. Survey conducted by SurveyMonkey/Recode, April 8-9, 2018, N-2,772 (Molla, 2018).

7. Survey conducted by Harris, October 9-11, 2018, $N=2,013$ (Vanian, 2018).

8. Lawmakers were faced with the prospect of a ballot measure, so they rushed to pass preemptive legislation (The New York Times, June 28, 2018; https://www .nytimes.com/2018/06/28/technology/california-online-privacy-law.html).

9. Janet Burns, "Facebook and Google are under fire for shady data. Why not Uber?" Forbes.com, April 18, 2018; https://www.forbes.com/sites/janetwburns/2018/04/ 18/facebook-is-under-fire-for-shady-data-habits-why-not-uber/\#76cc71da30cd. 
10. This paragraph draws on research Thelen conducted jointly with Christian Lyhne Ibsen.

11. http://www.x.mu.st/case/3f-uberman/. We thank Niels Fuglsang for drawing our attention to the Uberman campaign.

12. In the meantime, Amazon has abandoned its previous support for state-by-state regulation and now favors national legislation, which at this point in the company's development will impose a much greater burden on its competitors. Thanks to Alex Hertel-Fernandez for insights into the most recent developments.

13. Thanks to Akshay Mangla for bringing this case to our attention.

14. See also http://assembly.state.ny.us/member_files/075/issues/community_update /?update=201406.php

15. Some of these groups also organized sting operations to expose violations (e.g., Griswold, 2017).

16. We are grateful to Josh Simons for this insight.

\section{References}

Ash, T. G. (2013, June 27). If big brother came back, he'd be a public-private partnership. The Guardian. Retrieved from https://www.theguardian.com/commentisfree/2013/jun/27/big-brother-public-private-partnership-nsa

Baker, A. (2003). Why is trade reform so popular in Latin America? A consumptionbased theory of trade policy preferences. World Politics, 55, 423-455.

Baker, A. (2005). Who wants to globalize? Consumer tastes and labor markets in a theory of trade policy preferences. American Journal of Political Science, 49, 924-938.

Bauer, M. A., Wilkie, J. E. B., Kim, J. K., \& Bodenhausen, G. V. (2012). Cuing consumerism: Situational materialism undermines personal and social well-being. Psychological Science, 23, 517-523.

Block, F. (1980). Beyond relative autonomy: State managers as historical subjects. The Socialist Register, 17, 227-241.

Cadwalladr, C., \& Campbell, D. (2019, March 2). Revealed: Facebook's global lobbying against data privacy laws. The Guardian. Retrieved from https://www. theguardian.com/technology/2019/mar/02/facebook-global-lobbying-campaignagainst-data-privacy-laws-investment?CMP=share_btn_link

Cohen, J. E. (2016). The regulatory state in the information age. Theoretical Inquiries in Law, 17, 369-414.

Collier, R. B., Dubal, V. B., \& Carter, C. (2018). Disrupting regulation, regulating disruption: The politics of Uber in the United States. Perspectives in Politics, 16, 919-937.

Corporate Europe Observatory. (2018, May). UnFairbnb: How online rental platforms use the EU to defeat cities' affordable housing measures. TruePublica. Retrieved from https://truepublica.org.uk/eu/unfairbnb-how-online-rental-platforms-use -the-eu-to-defeat-cities-affordable-housing-measures/

Culpepper, P. D. (2011). Quiet politics and business power. New York, NY: Cambridge University Press. 
Culpepper, P. D. (2015). Structural power and political science in the post-crisis era. Business and Politics, 17, 391-409.

Culpepper, P. D., \& Reinke, R. (2014). Structural power and bank bailouts in the United Kingdom and the United States. Politics \& Society, 42, 427-454.

Davis, G. F. (2015). Corporate power in the twenty-first century. In S. Rangan (Ed.), Performance and progress: Essays on capitalism, business, and society (pp. 395-414). Oxford, UK: Oxford University Press.

Dubin, H. (2014, December 22). Manhattan bed \& breakfasts face extinction. Observer. Retrieved from https://observer.com/2014/12/manhattan-bed-breakfasts-face-extinction/

Dür, A., Bernhagen, P., \& Marshall, D. (2015). Interest group success in the European Union: When (and why) does business lose? Comparative Political Studies, 48, 951-983.

Edelman Trust Barometer. (2018). 2018 Edelman Trust Barometer Global Report. Retrieved from https:/www.edelman.com/sites/g/files/aatuss191/files/201810/2018_Edelman_Trust_Barometer_Global_Report_FEB.pdf

Emmenegger, P. (2015). The long arm of justice: U.S. structural power and international banking. Business and Politics, 17, 473-493.

Fairfield, T. (2015). Private wealth and public revenue in Latin America: Business power and tax politics. New York: Cambridge University Press.

Gaventa, J. (1980). Power and powerlessness: Quiescence and rebellion in an Appalachian valley. Urbana: University of Illinois Press.

Gellman, B., \& Poitras, L. (2013, June 7). U.S., British intelligence mining data from nine U.S. Internet companies in broad secret program. The Washington Post. Retrieved from https://www.washingtonpost.com/investigations/us-intelligence-mining-data -from-nine-us-internet-companies-in-broad-secret-program/2013/06/06/3a0c0da8 -cebf-11e2-8845-d970ccb04497_story.html?utm_term=.bc61d7a35b5a

Griswold, A. (2017, September 30). New York City is using sheriffs and obscure building code violations to crack down on Airbnb. Quartz. Retrieved from https:// qz.com/1084108/1084108/

Grossman, E., \& Woll, C. (2014). Saving the banks: The political economy of bailouts. Comparative Political Studies, 47, 574-600.

Hacker, J. S., \& Pierson, P. (2002). Business power and social policy: Employers and the foundation of the American welfare state. Politics \& Society, 30, 277-325.

Hacker, J. S., \& Pierson, P. (2017). American amnesia: How the war on government led us to forget what made America prosper. New York, NY: Simon \& Schuster.

Heemskerk, E. M. (2007). Decline of the corporate community: Network dynamics of the Dutch business elite. Amsterdam, The Netherlands: Amsterdam University Press.

Hempel, J. (2018, May 17). What happened to Facebook's grand plan to wire the world. Wired. Retrieved from https://www.wired.com/story/what-happened-tofacebooks-grand-plan-to-wire-the-world/

Hertel-Fernandez, A. (2014). Who passes business's "model bills"? Policy capacity and corporate influence in U.S. state politics. Perspectives on Politics, 12, 582-602. 
Hertel-Fernandez, A. (2019). State capture: How conservative activists, big business, and wealthy donors reshaped the American states-And the nation. New York, NY: Oxford University Press.

Hertel-Fernandez, A., Mildenberger, M., \& Stokes, L. (2019). Legislative staff and representation in Congress. American Political Science Review, 113, 1-18.

Hooghe, L., \& Marks, G. (2009). A postfunctionalist theory of European integration: From permissive consensus to constraining dissensus. British Journal of Political Science, 39, 1-23.

Jopson, B., \& Garrahan, M. (2011, July 12). Amazon urges California referendum on online tax. Financial Times. Retrieved from https://www.ft.com /content/61828252-ac1d-11e0-b85c-00144feabdc0

Kokolakis, S. (2017). Privacy attitudes and privacy behavior: A review of current research on the privacy paradox phenomenon. Computers \& Security, 64, 122-134.

Kurz, M. (2017, September 22). The mew monopolists. Project Syndicate. Retrieved from https://www.project-syndicate.org/commentary/monopoly-power-wealthincome-inequality-by-mordecai-kurz-1-2017-09?barrier=accesspaylog

Langley, P., \& Andrew L. (2017). Platform capitalism: The intermediation and capitalization of digital economic circulation. Finance and Society, 3, 11-31.

Lifsher, M., \& Chang, A. (2011, August 26). California lawmakers try to head off Amazon sales tax referendum. Los Angeles Times. Retrieved from https://www .latimes.com/business/la-xpm-2011-aug-26-la-fi-amazon-sales-tax-20110826 -story.html

Lindblom, C. E. (1977). Politics and markets. New York, NY: Basic Books.

Lindblom, C. E. (1982). The market as prison. The Journal of Politics, 44, 324-336.

Lukes, S. (2005). Power: A radical view (2nd ed.). Basingstoke: Palgrave Macmillan.

Lynch, D. J. (2017, October 30). Big tech and Amazon: Too powerful to break up?

Financial Times. Retrieved from https://www.ft.com/content/e5bf87b4-b3e511e7-aa26-bb002965bce8

Lynskey, O. (2017). Regulating "platform power" (London School of Economics Law, Society and Economy Working Papers 1/2017). London School of Economics and Political Science.

Miliband, R. (1969). The state in capitalist society. London, England: Quartet Books.

Mills, C. W. (1956). The power elite. New York, NY: Oxford University Press.

Mitchell, A., Grieco, E. M., \& Sumida, N. (2018, April 19). Americans favor protecting information freedoms over government steps to restrict false news online. Pew Research Center. Retrieved from http://www.pewresearch.org/2018/04/19 /americans-favor-protecting-information-freedoms-over-government-steps-to -restrict-false-news-online/

Mizruchi, M. S. (2013). The fracturing of the American corporate elite. Cambridge, MA: Harvard University Press.

Molla, R. (2018, April 10). Facebook is the least trusted major tech company. Recode. Retrieved from https:/www.recode.net/2018/4/10/17220060/facebook-trustmajor-tech-company 
Moore, M., \& Tambini, D. (Eds.). (2018). Digital dominance: The power of Google, Amazon, Facebook, and Apple. New York, NY: Oxford University Press.

Naoi, M., \& Kume, I. (2015). Workers or consumers? A survey experiment on the duality of citizens' interests in the politics of trade. Comparative Political Studies, 48, 1293-1317.

No vacancy: How Airbnb's New York City problem is just getting worse. (2017, April 3). Mashable. Retrieved from https://mashable.com/2017/04/03/airbnb -nyc-no-vacancy/?europe=true\#_RsfQXe67PqA

Packer, G. (2013, June 17). Big brother and Silicon Valley. The New Yorker. Retrieved from https://www.newyorker.com/news/daily-comment/big-brother-and-silicon-valley

Pagliari, S., \& Young, K. (2015). The interest ecology of financial regulation: Interest group plurality in the design of financial regulatory policies. Socio-Economic Review, 14, 309-337.

Posner, E., \& Weyl, G. (2018, May 1). The Real Villain Behind our New Gilded Age. The New York Times. Retrieved from https://www.nytimes.com/2018/05/01/ opinion/monopoly-power-new-gilded-age.html

Poulantzas, N. (1973). Political power and social classes. London, England: New Left Books.

Prasad, R. (2018). Ascendant India, digital India: How net neutrality advocates defeated Facebook's free basics. Media, Culture \& Society, 40, 415-431.

Przeworski, A., \& Wallerstein, M. (1988). Structural dependence of the state on capital. American Political Science Review, 82, 11-29.

Rahman, K. S. (2018). The new utilities: Private power, social infrastructure, and the revival of the public utility concept. Cardozo Law Review, 39, 101-171.

Rahman, K. S., \& Thelen, K. (2019). The rise of the platform business model and the transformation of twenty-first century capitalism. Politics \& Society, 47, 177-204.

Rogowski, R., \& Mark A. K. (2002). Majoritarian electoral systems and consumer power. American Journal of Political Science 46, 526-39.

Rossi, S. A. (2016). Internet privacy in the European Union and the United States (Master's thesis). European University Institute, Florence, Italy.

Scharpf, F. (1999). Governing in Europe: Effective and Democratic? New York, NY: Oxford University Press.

Schor, J. B. (1999). The overspent American: Why we want what we don't need. New York, NY: HarperPerennial.

Silicon Valley, We have a problem. (2018, January 20). The Economist. Retrieved from https://www.economist.com/briefing/2018/01/20/the-techlash-against -amazon-facebook-and-google-and-what-they-can-do

Soni, A. (2016, February 8). India deals blow to Facebook in people-powered "net neutrality" row. The Guardian. Retrieved from https://www.theguardian.com /technology/2016/feb/08/india-facebook-free-basics-net-neutrality-row

Srnicek, N. (2016). Platform capitalism. Cambridge, UK: Polity.

Stohr, G. (2013, December 2). Amazon rejected by US High Court on New York sales tax. Bloomberg. Retrieved from https://www.bloomberg.com/news/articles/2013-12-02/amazon-rejected-by-u-s-high-court-on-new-york-sales-tax 
Strahilevitz, L. J. (2013). Towards a positive theory of privacy law. Harvard Law Review, 126, 2010-2042.

Thelen, K. (2018). Regulating Uber: The politics of the platform economy in Europe and the United States. Perspectives on Politics, 16, 938-953.

Trumbull, G. (2006). National varieties of consumerism. Jahrbuch für Wirtschaftsgeschichte/Economic History Yearbook, 47, 77-94.

Tzur, A. (2017, June). Uber Über regulation? Regulatory change following the emergence of new technologies in the taxi market. Regulation \& Governance. Retrieved from https://onlinelibrary.wiley.com/doi/pdf/10.1111/rego.12170

Vanian, J. (2018, November 8). Facebook is the least trusted major tech company when it comes to safeguarding personal data, poll finds. Fortune. Retrieved from http://fortune.com/2018/11/08/mark-zuckerberg-facebook-reputation/

Vogel, D. (1987). Political science and the study of corporate power: A dissent from the new conventional wisdom. British Journal of Political Science, 17, 385-408.

Woll, C. (2008). Firm interests: How governments shape business lobbying on global trade. Ithaca, NY: Cornell University Press.

Woll, C. (2014). The power of inaction: Bank bailouts in comparison. Ithaca, NY: Cornell University Press.

Young, K. L. (2012). Transnational regulatory capture? An empirical examination of the transnational lobbying of the Basel Committee on Banking Supervision. Review of International Political Economy, 19, 663-688.

Young, K. L. (2015). Not by structure alone: Power, prominence, and agency in American finance. Business and Politics, 17, 443-472.

Zysman, J., \& Kenney, M. (2017). The next phase in the digital revolution. Communications of the ACM, 61, 54-63.

\section{Author Biographies}

Pepper D. Culpepper is blavatnik professor of Government and Public Policy at the Blavatnik School of Government at the University of Oxford. His current research investigates the relative influence of large companies, the media and public opinion on public policy.

Kathleen Thelen is ford professor of Political Science at MIT. She studies the political economy of the rich democracies with an emphasis, currently, on the American political economy in comparative perspective. 